\title{
The Influence of Social Commerce Factors on Customer Intention to Purchase
}

\author{
Abdul Kadir Othman ${ }^{1 *}$--- Lailatul Faizah Abu Hassan ${ }^{2}$--- Muhammad Iskandar Hamzah ${ }^{3}$--- \\ Amirun Razin Razali ${ }^{4}$--- Mohamad Amir Shah Saim ${ }^{5}$--- Mohd Safwan Ramli ${ }^{6}$-- \\ Muhammad Amir Osman ${ }^{7}$--- Mohamad Amirul Anbia Azhar ${ }^{8}$
}

${ }_{1,2,3,4,5,6,7,8}$ Faculty of Business Management, Universiti Teknologi MARA 40450 Shah Alam, Selangor, Malaysia. 'Email: abdkadir@salam.uitm.edu.my

\begin{abstract}
The rapid development in social commerce creates a new opportunity for businesses. With the use of social technologies they are able to create an environment that is on a socially interactive platform. These social bonds can drive online social support in e-commerce, the result is shown by trusts created and increased intention to use social commerce. This article will examine the factors that triggered consumers' intention to purchase using social commerce. $A$ total of 184 respondents were chosen for this study to investigate factors that might contribute to customers' purchasing intention. The findings provide a better understanding on factors that contribute to intention to purchase, which comprise shopping enjoyment, perceived usefulness, trust, security, perceived quality, perceived value, ease of use and transaction convenience. It also suggests that online firms should consider these contextual factors in order to facilitate consumers' adoption behavior.
\end{abstract}

Keywords: Ease of use, Security, Trust, Perceived value, Purchase intention.

Licensed: This work is licensed under a Creative Commons Attribution 4.o License.

Funding: This study received no financial support.

Competing Interests: The authors declare that they have no competing interests.

Acknowledgement: The authors would like to acknowledge the contribution of those involved in the preparation of this paper.

\section{Introduction}

The internet population has grown tremendously since its commercial introduction in 1991. The past decade has seen tremendous growth in retail transactions using electronic commerce platforms. Information technology and online platforms have stimulated impulse purchasing behavior by increasing consumer access to products and service. This is partly due to the easy process of purchasing and payment (Chen, Su and Widjaja, 2016).

Social commerce provides consumers the opportunity to shop online and consequentially creates customers' intention to purchase via click-and-mortar platforms. Social commerce is defined as "any commercial activities facilitated by or conducted through the broad social media and Web 2.0 tools in consumers' online shopping process or business' interactions with their customers" (Lin, Li and Wang, 2017). It is common for social commerce platforms to utilize sophisticated computer algorithms that could understand and respond to customers' behavioral patterns. This allows companies to offer the right products that match the exact needs of customers through electronic channels. Social commerce (s-commerce) is rapidly expanding worldwide, and it has various models including flash sales, group buying, social shopping, purchase sharing and personal shoppers (Kim and Eastin, 2011). Among these models, the most popular type of social commerce is group buying. The internet and social networking sites or SNS (Facebook, YouTube, and 
Twitter) are evolving day by day. In tandem with the rapid growth of online SNS users, the number of online suppliers is also expanding to cater the needs of the users.

Due to easy accessibility of the internet, customers feel free to create and share information regarding brands and products on social commerce and thus create value (Yadav, 2015). Currently, social commerce is rapidly gaining acceptance among consumers in developing countries including Malaysia, as a platform to shop online. The upward trend is expected to continue in the future. This positive outlook is mainly driven by several pull factors such as convenience, speed of transaction and accessibility. Other than that, consumers are increasingly shifting their focus from desktop computer to mobile platforms. The availability of various types of shopping applications and mobile payment systems means that there are a lot of options that customers can choose from. Luan and Teo (2009) claimed that the acceptance of new technology influences an individual's attitude and perception which result in adoption of new technology. Nevertheless, one of the main problems with social commerce is that certain people might feel insecure in accepting attractive deals offered in social media. Besides, not much is known on the factors that influence purchase intention over social commerce platforms within the context of Malaysian consumers. This is owing to the fact that some research has shown that the variance explained in behavioral tendency of using social commerce is still considered low (Hew, et al., 2016; Ng, 2013). Therefore, this paper is meant to identify factors that contribute to social commerce adoption to facilitate online purchase intention among Malaysian consumers.

\section{Literature Review}

\subsection{Customer Online Purchase Intention}

Online customer purchase intention can be characterized as the client's willingness to pay for a certain product after evaluating the available choices, and the risks and benefits of each of the options. According to George (2004) customers are willing to search, select and purchase products via the Internet but the advertisement must be creative enough to attract customers. This includes sharing of positive testimonies and user experiences by social media influencers and online celebrities. Organizations need to meet the requests of the buyers in order for purchase intention to build (Fortsythe and Shi, 2003). The online purchase is the result of purchase intention (Lee and Lee, 2015). Online purchase intention is a noteworthy indicator of actual purchase (Pavlou, 2003). Customers' genuine purchasing conduct is dichotomous on the grounds that shoppers either need to buy or not buy the product. In addition, online purchase goal is influenced by the buyers' assurance to buy from a web based business (Salisbury, Pearson, Pearson and Miller, 2001; Ling, Chai and Phew, 2010).

\subsection{Shopping Enjoyment}

The first factor that is expected to influence customers' online purchase intention is shopping enjoyment. Potential announcement of internet shopping comes from substantial online shopping knowledge. "Online shopping is a wilful and hedonic action, besides clients take an interest since they are characteristically spurred" (Shen, 2012). Consumers who appreciate shopping accomplish joy from shopping and investing energy perusing for items (Seock and Bailey, 2008).

The feeling of delight felt while going to a site can expand the online purchase expectation among purchasers by adding a charming shopping background, henceforth it is of extraordinary significance for organizations working on the web to perceive the effect of pleasure the site has to offer. According to Kim and Niehm (2009) a few items require a more top to bottom depiction and consequently it is proposed that $3 \mathrm{D}$ virtual models could be utilized. That sort of innovation on a site may prompt a more elevated amount of shopping delight among the buyers which at that point will upgrade the customers' purchase expectations.

\subsection{Perceived Usefulness}

The second factor that affect customers' online purchase intention is perceived usefulness of the online store. In the late 1990 s to the early 2000s, buying goods online could be regarded as a static and transactional affair. A decade later saw online commerce platforms started to embed dynamic and user-generated contents that allow users to rate their products and provide feedback in a transparent process. Consumers find themselves to be increasingly connected and engaged with each other by sharing their purchase and ownership experiences, which are highly useful for potential buyers to make the right purchase decisions. Since the perception of other user reviews can potentially shape consumers' expectation, the use of dynamic and shared content in social commerce platforms is expected to benefit them in assessing the values and risks associated with the particular product (Plotkina and Munzel, 2016). Perceived usefulness is one of the key variables in the classical Technology Acceptance Model (TAM) framework (Davis, 1989; Venkatesh, et al., 2003). Within the Malaysian context, perceived usefulness was found to influence consumers' intention to use mobile social commerce (Hew, et al., 2016) and purchase via social networking sites (Sin, Nor and Al-Agaga, 2012; Leng et al., 2011).

\subsection{Trust}

The third factor that is expected to contribute to customers' online purchase intention is trust. One of the most challenging issues of social network is building trust among users before they make purchases from the 
seller. According to Hajli (2015) to build customer trust for consumers is crucial. There are countless online sellers appearing every day advertising their products. An accurate website and frequent interaction enhances confidence toward the seller. Consumers gain trust and confidence by current customer reviews, ratings, and recommendations shared in the forums and communities. If the recommendations are positive, the level of trust would be higher towards the vendors. Trust is the willingness to accept the unpredictable consequences brought about by the third party behaviors.

The context of trust is divided into three. First is the ability of vendors to portray their capability to deliver according to customer expectations. Second is the integrity to meet and produce an output that satisfies customers. Lastly is benevolence which is empathy towards customers to fulfil their extraordinary expectations of the organization. According to Wright (2016) creating trust among consumers is the ultimate objective of social network provided by the organization as well as establishing a personal interaction and face to face contact. In a situation where the level of trust is high in the intention of purchase in social network, the consequences of perceived risk will be reduced by buying online.

\subsection{Security}

The fourth factor that is expected to influence customers' online purchase intention is security. When discussing online security, there are a lot of assumptions among users regarding their reluctance to share their personal information and use electronic transaction to avoid any misuse of information. In order to capture consumer confidence on security, sellers must provide secure approach that governs data protection such as identity verification and security policy. When sellers have implemented all possible security measures, consumers will have more confidence and make repeat purchases from online sellers, and if there is any issue such as late delivery or faulty product the sellers should provide a return and cash back guarantee (Ponte, Carvajal-Trujillo and Escobar-Rodríguez, 2015).

\subsection{Perceived Quality and Value}

The fifth factor that might affect customers' online purchase intention is perceived quality and value. Yen and $\mathrm{Lu}$ (2008) mentioned that customer expectation of the seller's service quality can be defined as the importance of the quality, including responsiveness, fulfilment of transaction, contact with seller and after sales service. There is some agreement to that statement where some studies on the effects of product quality, service quality and price fairness on customer loyalty found that service quality provides added value and leads to customer loyalty through customer satisfaction (Giovanis, Athanasopoulou and Tsoukatos, 2015). Good product and service quality are very important in today's competitive environment where many sellers offer the same type of service and product. Therefore, the first impression to customers on product and service quality is crucial in building a long term relationship with them.

Tahir and Guru (2017) mentioned that perceived product quality and perceived fair price affect perceived value equally whereby perceived value in turn, strongly affect online purchase intention. This relates to purchasing behavior where most customers will look up for the price tag first to ensure price reasonability. Tahir and Guru (2017) also added that perceived value is a measure between the quality of the product once customers really received the item and the price they actually paid. It can be concluded that, customer satisfaction is affected by the price perception, whereby it is an indirect outcome of the perception of price fairness (Bamfield, 2013).

\subsection{Ease of use and Transaction Convenience}

The sixth factor that might affect customers' online purchase intention is ease of use and transaction convenience. Social commerce enables people to have the convenience to shop online. According to Jiang and Rosenbloom (2005) among the technology characteristics, website performance, product information, product selection, ease of ordering, and shipping/handling have positive influences on customer perception of shopping convenience. Previous studies (Gupta and Kim, 2010) supported the idea that customers consider convenience as critical in adopting or conducting online shopping. Widely accepted literature suggests that the likelihood of customers to accept or use new technology will increase when the technology is considered easy to use, useful and convenient (Devaraj, et al., 2002).

According to Assael (2005) this is because people nowadays are living in an era of hectic and busy working lifestyles, and thus it has become very difficult for most people to go shopping outside their home. Moreover, based on a survey of over 5000 internet users, Assael (2005) suggested that heavy users of the internet are somewhat younger, growing up in the age of technology and taking advantage of it, and more likely to be workaholics and working more than 50 hours a week. In the same study, Assael (2005) also mentioned that heavy internet users are categorized as a multitasking group that tends to do more jobs or activities and seek to do more than they currently have on their plate. They may be "time starved" and are constantly exploring ways to reduce the time taken to complete various tasks to manage their busy schedules (Vijayasarathy, 2004). According to Poon (2008) the convenience of online shopping is that consumers are free to shop at different web sites and they are able to switch from one website to another with just a click.

The ease of access or accessibility refers to the degree to which a customer believes that accessing the internet via a mobile phone will be of little effort. In computer-related research, many studies have 
investigated ease of use but not ease of access. Several studies showed that users' perception on ease of use significantly influences users' intrinsic motivation (enjoyment or playfulness) (Hsu and Lu, 2007).

Mobile shopping service (MSS) is easier to access on the mobile internet and would be less intimidating to customers. Therefore, ease of access is expected to have a positive impact on customer's perception of enjoyment in mobile shopping context. Ease of use has been shown to play an important role in determining the intention to use (Mao, et al., 2005; Pijpers and van Montfort, 2005). Davis (1989) identified that freedom of effort in using a system is an important predictor for its adoption and subsequent usefulness. Much research has confirmed that the construct of freedom from effort has a strong effect on usefulness (Igbaria, et al., 1997; Luarn and Lin, 2005; McFarland and Hamilton, 2006). Very little research has looked into the effect of ease of access or accessibility from which an individual obtains a connection to mobile internet and their intention to purchase.

\section{Conceptual Framework}

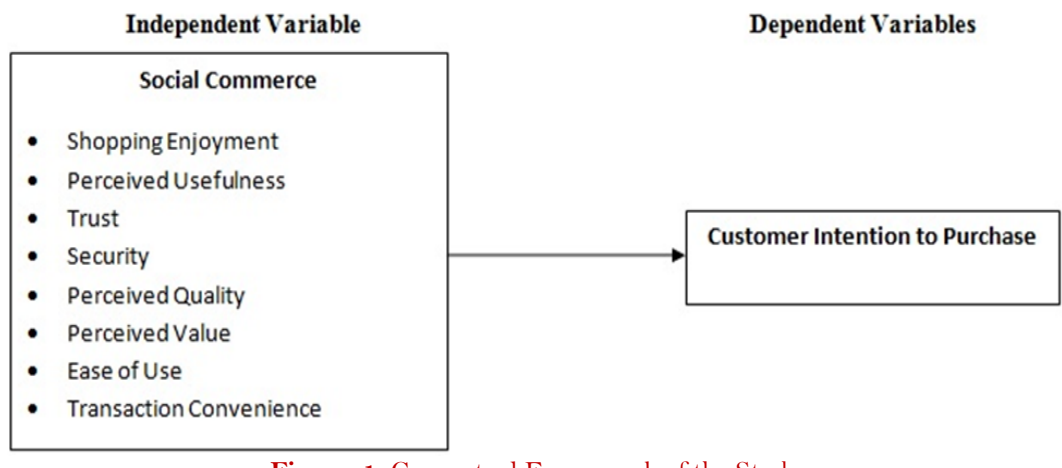

Figure-1. Conceptual Framework of the Study

Figure 1 above shows the conceptual framework of the study that explains the connection between each independent variable (social commerce factors) and the dependent variable (customer intention to purchase).

\subsection{Hypotheses}

Below are the research hypotheses highlighting the relationship between social commerce factors and customer intention to purchase.

H1: There is a significant relationship between shopping enjoyment and customers' online purchase intention

H2: There is a significant relationship between perceived usefulness and customers' online purchase intention

H3: There is a significant relationship between trust and customers' online purchase intention

H4: There is a significant relationship between perceived value and customers' online purchase intention

H5: There is a significant relationship between ease of use and customers' online purchase intention

H6: There is a significant relationship between security and customers' online purchase intention

H7: There is a significant relationship between perceived quality and customers' online purchase intention

H8: There is a significant relationship between transaction convenience and customers' online purchase intention

\section{Methodology}

The purpose of this study is to investigate the relationship between social commerce factors and customers' online purchase intention. This section includes research design, the instrument used for data collection, population and sample and data analysis.

\subsection{Research Design}

The research used non-experimental research approach that is a correlational research design. Correlational research involves the study of the relationship that exists between two or more variables without attempting to manipulate them and describe the degree to which those variables are related to each other. According to Salkind (2013) correlational research is used to identify how one or more variables relate to one another.

\subsection{Research instrument}

During the data collection period, the instrument used was a questionnaire. They were distributed directly to each of the respondents involved in this study. The questionnaire was designed precisely to answer the research question. The questionnaire was adapted from Lin (2017) to meet the requirements and verified by Associate Professor Dr Abdul Kadir Othman, a lecturer from Universiti Teknologi MARA, Shah Alam. 


\section{Results and Discussion}

\subsection{Response Rate}

In this study, a total of 184 questionnaires were distributed via Google Form. The questionnaires were sent via Facebook and WhatsApp application. The distribution and collection of responses took one week to complete. There were 184 respondents from various ages and from different educational backgrounds.

Table-1. Respondents' Profile.

\begin{tabular}{c|c|c|c}
\hline Variable & Description & Frequency & Percentage \\
\hline Gender & Male & 90 & 48.9 \\
\hline & Female & 94 & 51.1 \\
\hline Age & $20-30$ Years old & 152 & 82.6 \\
\hline & $31-40$ Years old & 16 & 8.7 \\
\hline & $41-50$ Years old & 12 & 6.5 \\
\hline Education & 51 Years old and above & 4 & 2.2 \\
\hline & SPM or below & 16 & 8.7 \\
\hline & Diploma & 42 & 22.8 \\
\hline & Bachelor's degree & 102 & 55.4 \\
\hline & Master's degree & 24 & 13.0 \\
\hline Marital Status & Doctorate & 0 & 0 \\
\hline & Single & 138 & 75.0 \\
\hline
\end{tabular}

Table-2. The results of Factor Analysis of the Independent Variables.

\begin{tabular}{|c|c|c|c|c|c|}
\hline & \multicolumn{4}{|c|}{ Component } & \multirow[b]{2}{*}{5} \\
\hline & 1 & 2 & 3 & 4 & \\
\hline $\mathrm{PV} 2$ & .882 & & & & \\
\hline $\mathrm{PQ}^{2}$ & .830 & & & & \\
\hline PV3 & .776 & & & & \\
\hline $\mathrm{PQ}_{4}$ & .773 & & & & \\
\hline PQ3 & .703 & & & & \\
\hline $\mathrm{PV} 4$ & .689 & & & & \\
\hline PV 1 & .688 & & & & \\
\hline $\mathrm{PQ}^{1}$ & .677 & & & & \\
\hline $\mathrm{EO} 4$ & & .871 & & & \\
\hline $\mathrm{EO} 1$ & & .760 & & & \\
\hline EO3 & & .725 & & & \\
\hline $\mathrm{EO} 2$ & & .666 & & & \\
\hline $\mathrm{TC} 2$ & & .617 & & & \\
\hline TC3 & & .609 & & & \\
\hline S3 & & & .912 & & \\
\hline $\mathrm{S}_{2}$ & & & .884 & & \\
\hline $\mathrm{S} 4$ & & & .879 & & \\
\hline $\mathrm{S}_{1}$ & & & .776 & & \\
\hline $\mathrm{T} 2$ & & & & .863 & \\
\hline $\mathrm{T} 1$ & & & & .772 & \\
\hline T3 & & & & .727 & \\
\hline $\mathrm{SE} 2$ & & & & & .817 \\
\hline SE3 & & & & & .737 \\
\hline SE 1 & & & & & .732 \\
\hline$\%$ variance explained $(76.626 \%)$ & 23.273 & 16.471 & 15.668 & 10.904 & 10.611 \\
\hline \multicolumn{4}{|c|}{ Kaiser-Meyer-Olkin Measure of Sampling Adequacy. } & & .880 \\
\hline \multirow{3}{*}{\multicolumn{2}{|c|}{ Bartlett's Test of Sphericity }} & \multicolumn{2}{|c|}{ Approx. Chi-Square } & & 4161.238 \\
\hline & & \multicolumn{2}{|c|}{$\mathrm{df}$} & & 267 \\
\hline & & \multicolumn{2}{|c|}{ Sig. } & & .000 \\
\hline \multicolumn{2}{|l|}{ MSA } & & & & $\begin{array}{l}.814- \\
.929\end{array}$ \\
\hline
\end{tabular}

Table 1 shows that the number of female respondents was slightly higher than male respondents which were represented by $94(51.1 \%)$ female and $90(48.9 \%)$ male respondents. In terms of age, Table 1 shows that 
the majority of the respondents were in the age range of 20-30 years old comprising $152(82.6 \%)$ respondents. This was followed by those between 31-40 years old at a total of $16(8.7 \%)$ respondents and those who were between 41-50 years old at 12 (6.5\%) respondents. The remaining four $(2.2 \%)$ respondents were 51 years old and above. In terms of educational background, it was found that majority of the respondents possessed bachelor degree qualification which summed up to $102(55.4 \%)$ respondents, followed by those who had Diploma qualification which comprised $42(22.8 \%)$ respondents. Meanwhile, $16(8.7 \%)$ respondents had SPM qualification. In addition, $24(22.8 \%)$ respondents had Master's Degree.

Table 2 shows the principle component factor analysis conducted in order to test the factor structure of the social commerce factors. The analyzed data signified a promising result where it had contributed to the creation of the five factor structure and in this case, it explained $76.626 \%$ of the total variance. The KMO measure of sampling adequacy projected a value of 0.880 which gave a clear indication that the items were interrelated. Apart from that, the Bartlett's Test of Sphericity offered a significant value in the sense that the Approx. Chi-Square value was to $4161.238, \mathrm{p}<$. O01. Hence, the analyzed results show the significance of the correlation matrix for factor analysis to be conducted.

Initially, there were eight independent variables but due to the similarities of the variables, the data had been merged into smaller number of variables. Perceived quality was merged with perceived value to become perceived quality and value. Ease of use was merged with transaction convenience and became ease of use and convenience. Perceived usefulness was removed due to high cross loadings. Other variables such as security, trust and shopping enjoyment remained as originally conceptualized.

Table-3. The Result of Factor Analysis of the Dependent Variables.

\begin{tabular}{|c|c|c|}
\hline & & Component \\
\hline & & 1 \\
\hline \multicolumn{2}{|c|}{ PI3 } & .868 \\
\hline \multicolumn{2}{|c|}{$\mathrm{PI} 2$} & .780 \\
\hline \multicolumn{2}{|l|}{$\mathrm{PI} 4$} & .753 \\
\hline \multicolumn{2}{|c|}{ PI1 } & .667 \\
\hline \multicolumn{2}{|c|}{ \% variance explained } & 59.387 \\
\hline \multicolumn{2}{|c|}{ Kaiser-Meyer-Olkin Measure of Sampling Adequacy. } & .673 \\
\hline \multirow{3}{*}{ Bartlett's Test of Sphericity } & Approx. Chi-Square & 220.657 \\
\hline & $\mathrm{df}$ & 6 \\
\hline & Sig. & .000 \\
\hline MSA & & $.652-.623$ \\
\hline
\end{tabular}

Table 3 shows the result of factor analysis for the dependent variable that is customers' online purchase intention. The result shows that the KMO value of .673 is sufficient for factor analysis to be conducted. Similarly, the MSA values between .652 and .623 show that the sampling is adequate for each item in the factor. Looking at the loadings of items, they are higher than .05, which indicate strong relationship between each item and the underlying factor. All four items were retained to represent purchase intention.

Table-4. The Results of Correlations and Reliability Analyses.

\begin{tabular}{|c|c|c|c|c|c|c|c|c|}
\hline No & Variables & Mean & SD & 1 & 2 & 3 & 4 & 5 \\
\hline 1 & Perceived Quality Value & 3.51 & .70 & $(.941)$ & & & & \\
\hline 2 & Ease of use convenience & 3.81 & .73 & $.719^{* * *}$ & $(.911)$ & & & \\
\hline 3 & Security & 2.34 & .97 & $.478^{* * *}$ & $.295^{* * *}$ & $(.938)$ & & \\
\hline 4 & Trust & 3.20 & .90 & $.485^{* * *}$ & $.467^{* * *}$ & $.540^{* * *}$ & $(.866)$ & \\
\hline 5 & Enjoyment & 3.66 & .88 & $.516^{* * *}$ & $.573^{* *}$ & $.365^{* *}$ & $.410^{* * *}$ & $(.805)$ \\
\hline 6 & Purchase Intention & 3.55 & .73 & $.665^{* * *}$. & $.676^{* * *}$ & $.253^{* * *}$ & $.446^{* * *}$ & $.578^{* * *}$ \\
\hline
\end{tabular}

Table 4 shows the correlation analysis between social commerce and purchase intention. There was a positive relationship between independent variables and dependent variables. The results show that the highest correlation is between purchase intention and ease of use $(r=.676 ; p<01)$, followed by the correlation between perceived quality and value and purchase intention $(\mathrm{r}=665 ; \mathrm{p}<01)$. Security has the lowest correlation with purchase intention $(\mathrm{r}=.253 ; \mathrm{p}<.01)$. The results indicate the existence of concurrent validity of the factors measuring social commerce and online purchase intention. The correlation between one independent variable with another independent variable ranges from low $(\mathrm{r}=.295 ; \mathrm{p}<.01)$ for ease of use/convenience and security, to high correlation for ease of use and convenience and perceived quality and value $(\mathrm{r}=.719 ; \mathrm{p}<.01)$, indicating convergent validity of the factors constituting social commerce. All items are relible to measure the intended variables, which can be seen from the Cronbach's alphas that range from .805 to .958 . 
Table-5. The Results of Multiple Regression Analysis.

\begin{tabular}{c|c}
\hline Variables & Standardized Beta \\
\hline Perceive Quality and Value & $.365^{* *}$ \\
\hline Ease of Use and Convenience & $.257^{* *}$ \\
\hline Trust & $.135^{* *}$ \\
\hline Security & -.160 \\
\hline Enjoyment & $.245^{* *}$ \\
\hline $\mathrm{R}$ & .760 \\
\hline $\mathrm{R}^{2}$ & .578 \\
\hline $\mathrm{F}$ value & 48.728 \\
\hline Sig. F value & .000 \\
\hline Durbin Watson & 2.196 \\
\hline Notes: **. Significant at the 0.01 level. &
\end{tabular}

Table 5 shows the result of regression analysis which explains the percentage of variance in the dependent variable (customers' online purchase intention), which was explained by the social commerce factors. The $\mathrm{R}$ squared value of .578 indicates that $57.8 \%$ of the variance was explained. The $\mathrm{F}$ value is significant showing that the regression model is good at explaining the dependent variable. Durbin Watson value of 2.196 denotes the absence of auto correlation in the model. Looking at the contribution of the individual independent variable in explaining customers' online purchase intention, four out of five factors are significant. The strongest predictor is perceived quality and value $(\beta=.365 ; \mathrm{p}<.01)$. It is followed by ease of use and convenience $(\beta=.257 ; \mathrm{p}<.01)$, enjoyment $(\beta=.245 ; \mathrm{p}<.01)$, and trust $(\beta=.135 ; \mathrm{p}<.01)$. Interestingly, security has no significant influence on purchase intention $(\beta=-.160 ; \mathrm{p}>.05)$.

\section{Discussion}

This study has several key findings; first, the results confirm the significant positive impact of perceived quality and value, ease of use and convenience, enjoyment and trust on purchase intention in the context of social commerce. A substantial degree of quality, convenience in using the social commerce, enjoyment and trust are needed by online buyers before making purchase decisions.

Thus, this study upholds the claim that these factors are important in social commerce and it is extended to the context of e-commerce. Second, the results did not support the hypothesis on the role of security in relation to purchase intention. Although studies have claimed that security is the most pertinent factor in affecting purchase intention, this present study failed to provide the evidence required to support it. In social commerce, where the exchange of sensitive information is not required, the aspect of security has become irrelevant.

Customers use social commerce to get the required product information, reviews and feedback before advancing to the next stage of purchasing the product. Therefore, the finding is well-justified. Finally, by looking into buyers' behavior in online commerce marketplace, it was learned that social commerce poses the biggest effect that influences purchase intention that deserves more attention in future studies. Social influence in purchase intention has been overlooked or simplified in prior literature; however, the mushrooming of social commerce has called for more attention to the social perspective of purchase intention.

\section{Implications of the Study}

This study is expected to provide theoretical, practical, methodological implications for further studies. These five aspects are expected to provide a scientific understanding of related responsibilities in an effort to develop theories according to the field of study which are the responsibility of the researcher. Moreover, the implications of this study are also expected to provide recommendations to marketers regarding efforts that should be linked with the studied problems.

Theoretically, this research provides the foundation or framework depicting the influence of social commerce factors on customers' intention to purchase online. It is based on the uniqueness in this research that gives a different perspective from previous studies. The uniqueness can be seen from the identified variables that have been modelled and adjusted to research setting in Malaysia. Furthermore, this research is also expected to be discussed further, so that it can be developed and tested in different research settings.

Practically, this study is valuable for marketers because it is expected to provide insights associated with the concept of social commerce factors toward customers' intention to purchase online. Understanding the concept of social commerce factors can provide a broader perspective on the purchase intention that can be used to design strategies to increase sales for online retailers. In addition, this study can be used as a reference for online marketers to customize the marketing strategies according to what customers want. It is expected that this study could enrich theoretical understanding on the role of social commerce.

Online retailers or business owners should take proper steps in investing some of their capital to enhance their services for example in website performance, products information, product selection, ease of ordering, and shipping/handling which are related to quality, ease of use or convenience, enjoyment and trust in creating purchase intention, so that they can attract more customers to engage in online purchase and 
subsequently generate more income. Furthermore, the experience of customers while interacting with retailers must be desirable so that they will be excited in prolonging the relationship with the retailers.

\section{Limitations and Suggestions for Future Research}

While this study contributes to extending the body of social commerce on purchase intention research, several limitations should be recognized. First, the sample was limited to university students; thus the results may not represent the Malaysian population in general.

The majority of the respondents consisted of Universiti Teknologi MARA students of the Faculty of Business and Management located in Shah Alam, therefore the results may not characterize individuals from diverse backgrounds and other specific regions of the country. Extending the study to other regions of Malaysia would contribute greatly to the understanding of consumer intentions to use social commerce while shopping for fashion products.

Second, the present study focused on an investigation of millennial consumers' perceived ease of use of social commerce, usefulness, and enjoyment, which influenced their attitudes and intentions to use social commerce when shopping for fashion products. A majority of the participants were 20 to 30 years of age $(82.6 \%)$, whereby the lifestyle of the participants and their previous experiences with social media may affect the findings of this study.

Third, this study examined the relationships among perceived ease of use, usefulness, enjoyment, trust, and customer purchase intention to shopping for fashion products. The focus on shopping for fashion products affects the generalizability of the results on other product categories. To increase the validity of the model, future research should be conducted for other product categories. Further investigation is needed to explore other factors (e.g., perceived risks and ease of use) that affect product purchase through social commerce.

\section{Conclusion}

The general purpose of this study was to identify the social commerce factors affecting customers' online purchase intention. The conclusion deliberates the overall overview of the findings discussed in the results. The result of the study shed insights on online purchasing intention; specifically, the significant key factors affecting customers' online purchase intention.

The findings contributed to the conclusion that perceived quality/ value, ease of use/ convenience, trust and enjoyment are the significant factors that affect customer's intention to purchase. It can be explained that millennials especially are more concerned about purchasing products in an efficient and timely manner with the least effort. However, security gave a non-significant result in the study.

This can be explained given that social commerce is in it preliminary phase of online shopping where the exchange of sensitive or confidential information has yet to happen. Although non-significant, the role of security on social commerce is well-explained. Finally, it is expected that this research may provide information that would be useful to online retailers and marketers, to customers and also large organisations.

\section{References}

Assael, H. (2005). A demographic and psychographic profile of heavy internet users and users by type of internet usage. Journal of Advertising Research, 45(1): 93-123.

Bamfield, J. (2013). Retail futures 2018: Shop numbers, online and the high street: A guide to retailing in 2018. Centre for Retail Research Limited, 16(2): 5-14.

Chen, J.V., Su, B.C. \& Widjaja, A.E. (2016). Facebook $\mathrm{C}_{2} \mathrm{C}$ social commerce: A study of online impulsebuying. Decision Support Systems, 83: 57-69.

Davis, F.D. (1989). Perceived usefulness, perceived ease of use, and user acceptance of information technology. MIS Quarterly, 13(3): 319-340.

Devaraj, S., Fan, M. \& Kohli, R. (2002). Antecedents of B2C channel satisfaction and preference: Validating ecommerce metrics. Information Systems Research, 13(3): 316-333.

Forsythe, S. \& Shi, B. (2003). Consumer patronage and risk perceptions in internet shopping. Journal of Business Research, 56(11): 867-875.

George, J.F. (2004). The theory of planned behavior and internet purchasing. Internet Research, 14(3): 198212.

Giovanis, A., Athanasopoulou, P. \& Tsoukatos, E. (2015). The role of services fairness in the service quality relationship quality - customer loyalty chain: An empirical study. Journal of Service Theory and Practice, 25(6): 744-776

Gupta, S. \& Kim, H.W. (2010). Value-driven internet shopping: The mental accounting theory perspective. Psychology \& Marketing, 27(1): 13-35.

Hajli, N. (2015). Social commerce constructs and consumer's intention to buy. International Journal of Information Management, 35(2): 183-191.

Hew, J. J., Lee, V. H., Ooi, K. B. \& Lin, B. (2016). Mobile social commerce: The booster for brand loyalty?. Computers in Human Behavior, 59: 142-154.

Hsu, C. L. \& Lu, H. P. (2007). Consumer behavior in online game communities: A motivational factor perspective. Computers in Human Behavior, 23(3): 1642-1659. 
Igbaria, M., Zinatelli, N., Cragg, P. \& Cavaye, A.L.M. (1997). Personal computing acceptance factors in small firms: A structural equation model. MIS Quarterly, 21(3): 279-305.

Jiang, P. \& Rosenbloom, B. (2005). Customer intention to return online: Price perception, attribute-level performance, and satisfaction unfolding over time. European Journal of Marketing, 39(1/2): 150-174.

Kim, H. \& Niehm, L. S. (2009). The impact of website quality on information quality, value, and loyalty intentions in apparel retailing. Journal of Interactive Marketing, 23(3): 221-233.

Kim, S. \& Eastin, M. S. (2011). Hedonic tendencies and the online consumer: An investigation of the online shopping process. Journal of Internet Commerce, 10(1): 68-90.

Lee, J. \& Lee, J. (2015). How purchase intention consummates purchase behaviour: The stochastic nature of product valuation in electronic commerce. Behaviour \& Information Technology, 34(1): 57-68.

Leng, G. S., Lada, S., Muhammad, M. Z., Ibrahim, A. A. H. A. \& Amboala, T. (1970). An exploration of social networking sites (SNS) adoption in Malaysia using technology acceptance model (TAM), theory of planned behavior (TPB) and intrinsic motivation. The Journal of Internet Banking and Commerce, 16(2): 1-27.

Lin, X., Li, Y. \& Wang, X. (2017). Social commerce research: Definition, research themes and the trends. International Journal of Information Management, 37(3): 190-201.

Ling, K. C., Chai, L. T. \& Piew, T. H. (2010). The effects of shopping orientations, online trust and prior online purchase experience toward customers' online purchase intention. International Business Research, 3(3): $63-76$.

Luan, W. S. \& Teo, T. (2009). Investigating the technology acceptance among student teachers in Malaysia: An application of the technology acceptance model (TAM). The Asia-Pacific Education Researcher, 18(2): 261-272.

Luarn, P. \& Lin, H.H. (2005). Toward an understanding of the behavioral intention to use mobile banking. Computers in Human Behavior, 21(6): 873-891.

Mao, E., Srite, M., Thatcher, J.B. \& Yaprak, O. (2005). A research model for mobile phone service behaviors: Empirical validation in the US and Turkey. Journal of Global Information Technology Management, $8(4): 7-28$.

McFarland, D.J. \& Hamilton, D. (2006). Adding contextual specificity to the technology acceptance model. Computers in Human Behaviour, 22(3): 427-447.

$\mathrm{Ng}$, C. S. P. (2013). Intention to purchase on social commerce websites across cultures: A cross-regional study. Information \& Management, 50(8): 609-620.

Pavlou, P. A. (2003). Consumer acceptance of electronic commerce: Integrating trust and risk with the technology acceptance model. International Journal of Electronic Commerce, 7(3): 101-134.

Pijpers, G.G.M. \& Van Montfort, K. (2005). An investigation of factors that influence senior executives to accept innovations in information technology. International Journal of Management, 22(4): 542-555.

Plotkina, D. \& Munzel, A. (2016). Delight the experts, but never dissatisfy your customers! A multi-category study on the effects of online review source on intention to buy a new product. Journal of Retailing and Consumer Services, 29: 1-11.

Ponte, E. B., Carvajal-Trujillo, E. \& Escobar-Rodríguez, T. (2015). Influence of trust and perceived value on the intention to purchase travel online: Integrating the effects of assurance on trust antecedents. Tourism Management, 47: 286-302.

Poon, W.C. (2008). Users' adoption of e-banking services: The Malaysian perspective. Journal of Business \& Industrial Marketing, 23(1): 59-69.

Salisbury, W. D., Pearson, R. A., Pearson, A. W. \& Miller, D. W. (2001). Perceived security and world wide web purchase intention. Industrial Management \& Data Systems, 101(4): 165-177.

Salkind, N. J. (2013). Exploring research: Pearson new international edition. Pearson Higher Ed.

Seock, Y. \& Bailey, L. (2008). The influence of college students' shopping orientations and gender differences on online information searches and purchase behaviours. International Journal of Consumer Studies, 32(2): 113-121.

Shen, J. (2012). Social comparison, social presence, and enjoyment in the acceptance of social shopping websites. Journal of Electronic Commerce Research, 13(3): 198-212.

Sin, S. S., Nor, K. M. \& Al-Agaga, A. M. (2012). Factors affecting Malaysian young consumers' online purchase intention in social media websites. Procedia-Social and Behavioral Sciences, 40: 326-333.

Tahir, M.N. \& Guru, P. (2017). What factors determine e-satisfaction and consumer spending in e-commerce retailing. Journal of Retailing and Consumer Services, 39: 135-144.

Venkatesh, V., Morris, M. G., Davis, G. B. \& Davis, F. D. (2003). User acceptance of information technology: Toward a unified view. MIS Quarterly, 27(3): 425-478.

Vijayasarathy, L. R. (2004). Predicting consumer intentions to use on-line shopping: The case for an augmented technology acceptance model. Information \& Management, 41(6): 747-762.

Wright, K. B. (2016). Communication in health-related online social support groups/communities: A review of research on predictors of participation, applications of social support theory, and health outcomes. Review of Communication Research, 4: 65-87. 
Yadav, R. (2015). An exploration into the nature of comments on Facebook (page of large Indian organizations). In Managing in Recovering Markets. New Delhi: Springer. pp: 103-112.

Yen, C. H. \& Lu, H. P. (2008). Effects of e-service quality on loyalty intention: An empirical study in online auction. Managing Service Quality: An International Journal, 18(2): 127-146. 